\title{
INNOVATION EXPERIENCE OF ENTREPRENEURS OF HIGH TECH SMES IN TURKEY
}

\author{
DOI: 10.17261/Pressacademia.2017.507
}

JBEF- V.6-ISS.2-2017(13)-p.177-190

\section{Dilek Demirbas ${ }^{1}$}

${ }^{1}$ istanbul University, Faculty of Economics, ìstanbul, Turkey. dilek.demirbas@istanbul.edu.tr

\section{To cite this document}

Demirbas, D., (2017). Innovation experience of entrepreneurs of high tech SMEs in Turkey. Journal of Business, Economics and Finance (JBEF), V.6, Iss.2, p.177-190.

Permemant link to this document: http://doi.org/10.17261/Pressacademia.2017.507

Copyright: Published by PressAcademia and limited licenced re-use rights only.

\begin{abstract}
Purpose- The goal of this study is to explore and define the barriers to innovation perceived and experienced by entrepreneurs of High Tech SMEs in Turkey.

Methodology- In order to investigate the research question, an online questionnaire that was created for the purpose of this analysis. Questionnaire consists of 25 questions covering up four groups of barriers to innovation (formal, informal, environmental and skill barriers). In total, $225 \mathrm{High}$ Tech SME entrepreneurs from the Istanbul region completed the questionnaire. Logit models were estimated using the Eviews software programme.

Findings- An analysis of 225 High Tech Turkish SME entrepreneurs reveals the fact that "lack of sufficient government's R\&D and technology policy" from formal barriers; "Informal economy's negative impact on investment" from informal barriers; "high cost of innovation" and "lack of appropriate source of finance" from environmental barriers and "lack of qualified personnel" from skill barriers, are the most important barriers, which have significant effects on the entrepreneurs' innovation decisions in Turkey.

Conclusion- The survey results show that entrepreneurs, who know how to innovate, are those who have more perception of the barriers to innovation. However it is observed through the logistic regression model that some of the relations established between the barriers to innovation and the entrepreneurial innovative capacity are not statistically significant.
\end{abstract}

Keywords: High Tech SMEs, Barriers to Innovation, Entrepreneur, Turkey

JEL Codes: D01, D04, M21, M12

\section{INTRODUCTION}

The term 'innovation' originates from the Latin 'innovate', meaning to take something new. The term 'entrepreneur' was first introduced by an economist Richard Cantillon, defining the entrepreneur as the "agent who buys means of production at certain prices in order to combine them" into a new product. The conceptual relationship between innovation and entrepreneurs has attracted considerable attention in the economic literature for many years. Some theoretical attempts to establish a link between entrepreneur and innovation came from economics (Mill, 1848; Marshall, 1890; Schumpeter, 1951; Kirzner 1985; Leibenstein, 1995; Drucker, 1985, 1994; Buggie, 2001; Herbig et al., 1994; Hargadon and Sutton, 2000). Drucker (1985, p. 32) states that: "innovation is the specific tool of entrepreneurs". Drucker's definition shows that incorporating innovation is a key challenge facing entrepreneurs and small to medium-sized enterprises (SMEs, Tidd et al., 2001). Nevertheless, in many SMEs, basic operational functions are carried out by the owner or manager, and not by the innovative entrepreneur, and thus this challenge often leads to a lack of realisation of the processes needed to implement 
innovation within the SME. In order the overcome this challenge, small businesses actually need entrepreneurs in order to transfer their knowledge and their information into very successful practices throughout continuous innovation at every level (OECD LEED Programme, 2009). So that, without any doubt, innovation should be intrinsically linked to the entrepreneurial operation within SMEs wherever they operate. In the literature, small entrepreneurial firms are generally credited with introducing several radical innovations (Utterback, 1994), especially in industries characterised by skilled labour and low capital intensity (Acs and Audretch 1988).

In addition to the challenges mentioned earlier, several studies (Davidsson 1989, Hakim 1989; Storey, 1994) also showed that most small firms are, in fact, not very entrepreneurial or innovative; and these firms experience difficulty in acquiring external capital for rapid growth and managerial skill to cope with the increasingly complex organisational process; they often lack the time and resources to identify external sources of information and technical expertise; they have difficulty attracting risk capital; and they have difficulties in responding properly to their markets. Therefore, these disadvantages of SMEs in relation to innovation are often called barriers to innovation. Despite the interest in improving knowledge about barriers to innovation, there has been little research in the field of main innovation barriers for entrepreneurs from the economic literature perspective. The main aim of this paper is to understand the innovation barriers for Turkish high tech SME entrepreneurs from the economic perspective. Once barriers to innovation are removed that would increase innovation and growth in the small firm sector, and consequently boost economic growth. To do so, some formal and informal, as well as skill and environmental barriers perceived and experienced by high tech SME entrepreneurs in Turkey should be identified through a survey questionnaire, in order to comprehend what prevents entrepreneurs being more innovative. This paper is structured as follows: Section 2 provides the theoretical background of innovation barriers for SME entrepreneurs. Section 3 discusses the Turkish SMEs and country specific barriers, Section 4 looks into research methodology and data in detail and presents empirical findings on questionnaire survey. Findings and policy implications form the conclusion in Section 5.

\section{LITERATURE REVIEW}

Even in industrialised countries, SMEs are expected to face relatively more barriers to innovation than large firms. Keegan et al. (1997) and Cooney et al. (1996) have focused on barriers to innovation in European SMEs and found that some of these barriers are shared across countries and some of them are country-specific. Nevertheless, common barriers, according to Keegan et al (1997), are as follows; 'high costs associated with innovation', 'too long pay-off period for innovations', 'lack of government support for business', 'low availability of venture capital', 'innovations are too easy to be copied by competitors', 'high rates of income tax and social insurance', the 'small size of the domestic market', 'national tendency towards jobs with security', an 'education system that influences people to get a job', and a 'national tendency to recent successful entrepreneurs'. These high number of innovation barriers proves that there is a need for a clear strategy for SMEs to deal with these basic barriers to their position and to implement innovation practices within the firm (Teece, 1996). Irrespective of the scenario of the strategy adopted by the small business it is crucial to know that the small business entrepreneur should implement the best policy to implement their innovation decisions. As SMEs have comparatively more inadequate internal resources and lack of expertise, the interactive character of innovation in their case becomes even more intense than in large firms (Rothwell, 1991). This is one of the reasons that higher importance is attached to barriers. It is generally believed that once SME entrepreneurs identify their innovation barriers, study their impacts and take actions to eliminate them, then the natural flow of innovation will be re-established and maintained. Because innovation is not an automatic or spontaneous process it requires entrepreneurs to provide motivation, effort and risk acceptance to proceed (Tidd et al., 1997). Piatier (1984) carried out research for the Commission of European Communities, under the title "Barriers to innovation in SME" in eight countries of the European Economic Community, and differentiated barriers as external to the firm (supply, demand and environment related) and internal to the firm (resource related and human nature related) ${ }^{1}$. For Rush and Bessant, 1992 these barriers may act on one or more points of the innovation process. In his study, Piatier (1984) found that impacts are mainly on finance, manufacture and manpower. General government action, which is estimated to cause about half of the difficulties experienced, has its strongest negative impact upon the downstream end of the innovation process (i.e. distribution and exports). After Piatier (1984) barriers to innovation in SMEs have been the object of investigation in a large body of national and international studies, and among them; Acs and Audretsch (1990) for the US; Ylinenpää (1998) for Sweden; Hadjimanolis (1999) for Cyprus; Mohnen and Rosa (2002), Baldwin and Lin (2002), and Baldwin and Gellatly (2004) analyzed the obstacles to innovation in a sample of service and manufacturing firms for Canada; FES (2004) for Germany; Mohen and Röller (2005) studied the complementarities between barriers to innovation with a sample of the CIS1 data from Ireland, Denmark, Germany and Italy; Galia and Legros (2004) investigated the complementarities between obstacles to innovation using CIS2 data for a

\footnotetext{
${ }^{1}$ Resource related, e.g. lack of internal funds, technical expertise or management time; culture and systems related e.g. out-of date accountancy systems; and human nature related, e.g. attitude of top manager to risk or employee resistance to innovation
} 
sample of manufacturing firms for France; Freel (2005) observed the barriers to product innovation in a sample of small manufacturing firms in the West Midlands for the West Midlands area; March et al. (2002) analysed empirically the barriers to innovation in a small sample of SMEs located in the Valencia region of Spain. These can be counted as pioneer studies. Segarra-Blasco et al in 2008 used a data set in their research which was 2004 official innovation survey of Catalonia and used a sample of 2,954 Catalan firms in manufacturing industries and knowledge-intensive services. For these researchers, managers and owners of firms considered these obstacles to innovation as external and internal factors. External barriers become visible when the firm has difficulties accessing technological information, or when it lacks external finance, or skilled personnel, or when there are factors related the market conditions. A firm has internal barriers when it lacks internal funds and when the firm's members feel that the risks and costs of innovation are too high.

In their study, Madrid-Guijarro et. al (2009) examined barriers to firm innovation among a sample of 294 managers of SMEs in Spain, and evaluated the relation between product, process, and management innovation; and 15 obstacles to innovation, which can limit a firm's ability to remain competitive and profitable. Findings of the study show that barriers have different kinds of impact on the various types of innovation. For example, product, process, and management related innovations are affected differently by the various barriers. The most significant barriers are associated with costs, whereas the least significant are associated with manager/employee resistance. Additionally, the results demonstrate that the costs associated with innovation have proportionately greater impact on small than on larger firms. They suggested that the findings can be used in the development of public policy aimed at supporting and encouraging the innovation among SMEs in Spain. In addition to all those general problems mentioned above, SMEs in less developed countries face further barriers, such as; lack of technological and policy infrastructure, the low degree of innovativeness, bad location and inappropriate firm size for the market. In addition to these, comprehensive studies on barriers to innovation in such countries are relatively rare. There are limited but still some studies for less developed countries to examine barriers to innovation. For example, Levy (1993) examined barriers to growth and Lall et al. (1994) studied technological development in less developed countries. Governments in those countries make serious efforts to reduce these barriers in order to improve innovation activities for SMEs and to increase their international competitiveness, but still the number of regulations or lack of technology policy of governments can be counted among the most important barriers for SMEs and their entrepreneurs. In addition, internationalisation activities of developing countries expose SMEs to a more complex and risky business environment compared to larger firms. SMEs are also relatively unprepared for competition and less well-resourced in those countries. Another very important reason might be that there are so many formal and informal barriers to innovation in less developed countries (Some of these risks, barriers and complexities have been already addressed by some economists (such as; Stewart, 1977; Lall, 1983; Fransman, 1985; Kumar and Sagip, 1996; Evanson and Johnson, 1998; Johnson et. al. 2000; Glas et. al., 2000; Pissarides et.al., 2000; Woodword, 2001; and Anderson et. al., 2004).

Bobera (2013) explored the barriers to innovation perceived by entrepreneurs in Northern-Backa region, and identified the most significant barriers that have strong, negative influence on a process of creating a healthy, competitive entrepreneurship environment for development of innovation with special direction to three areas of barriers: organizational, formal and informal barriers.This study recommended following actions: understanding barriers to innovation in order to minimize their influence, fostering an innovation culture, increasing a number of successful inovations. Baron and Tang (2009) also indicated that positive affect among founding entrepreneurs is significantly related to their creativity and that creativity, in turn, is positively related to firm-level innovation. Both of these relationships are moderated by environmental dynamism, being stronger in highly dynamic than stable environments. For the creation of a more business friendly innovation environment, and for a more integrated economy at the international level it is obvious that governments in less developed countries should harmonise their regulatory, administrative and policy environments to world standards.

\section{FOUR CATEGORIES OF BARRIERS TO INNOVATIONS IN TURKEY}

The size of the informal sector in Turkey is a very important barrier. According to OECD (2004) estimates, there are more than four million in total registered-unregistered SMEs in Turkey, and the informal economy could represent about $50 \%$ of the activity of SMEs. In order to reduce the size of the informal sector in Turkey, Turkish governments have implemented very detailed programs but it still stands as one of the most important barriers for SME entrepreneurs to be more innovative. In addition to the informal sector, financing is also another handicap to improve or to develop the innovation culture in SMEs. As the Turkish banking system is not well equipped and prepared to provide investment funds to SME entrepreneurs, Turkish governments have created a number of targeted investment credit programmes in support of SMEs. However, this support is not enough for SMEs to overcome their basic problems. Beside the lack of funding, Turkish SMEs also appear to suffer from a lack of industrial space, a lack of information and efficient production technology, scant use of management and control systems, an inability to access consulting services, a lack of computer knowledge and 
related deficiencies. Most countries experience these shortcomings to varying extents, but they seem especially significant in Turkey (OECD, 2004, p.19).

Following the literature, four types of barriers to innovation for SME entrepreneurs, in addition to firm specific determinants, are specified in this research. These are;

i) formal barriers (such as government's weak R\&D policy, instability of tax policies, too much business legislation, insufficient property rights, and too many regulations and standards e.g. Bobera (2013); Piatier (1984); Acs and Audretsch (1990); Hadjimanolis (1999); Baldwin and Gellatly (2004); Silva et. al. (2007); Tourigny and Le (2004): Rush and Bessant (1992); Hadjimanolis (1999); Rammer et al. (2006));

ii) informal barriers (corruption, impact of informal economy, misleading cultural attitudes and a lack of transparency, e.g. Baldwin and Gellatly (2004); Hadjimanolis (1999), Bobera (2013); Segarra-Blasco et al (2008), Silva et. al. (2007); Tourigny and Le (2004));

iii) environmental barriers (excessive perceived economic risks, the high cost of innovation, high inflation and interest rates and the lack of appropriate sources of finance, e.g. Acs and Audretsch (1990); Bobera (2013); Hadjimanolis (1999); Rammer et al. (2006); Baldwin and Gellatly (2004); Silva et. al. (2007); Tourigny and Le (2004); Baron and Tang (2009)); and

iv) skill barriers (lack of qualified personnel, lack of information on markets and the lack of information on technology, e.g. Segarra-Blasco et al (2008); Silva et. al. (2007); Tourigny and Le (2004); Ylinenpää (1998); Rammer et al. (2005); Rammer et al. (2006)). These barriers will be examined empirically in more detail in section 4.

\section{DATA AND METHODOLOGY}

\subsection{Survey, Data, Hypotheses}

To examine the determinants of barriers to innovation among High Tech SME entrepreneurs in Turkey, a survey questionnaire was prepared in 2011. First of all, the four-page questionnaire containing a total of 25 questions was sent to 20 Turkish High Tech SME participants as a pilot study in order to capture the key barriers for entrepreneurs to innovate. Then, based on responses, some important adjustments were carried out and the final questionnaire was randomly sent to 525 High Tech SME entrepreneurs selected from the state statistics and KOSGEB's list. Out of 525 High Tech SMEs, 265 High Tech SMEs responded to the survey giving a 55\% response rate of which 225 SMEs were selected from as the intention was to select High Tech SMEs only for this study. These 225 High Tech SMEs and their characteristics can be seen in Table 2. The subjective responses of SME entrepreneurs provide us with insights into the actual barriers and it is a valuable technique for understanding the key issues concerning barriers. However, this survey has its own merits; it has also it own limitations. Firstly, it is a static study and so captures at best "certain aspects of reality at a moment in time" (Johnson and Loveman, 1995). Second, it is also possible that a percentage of respondents did not express their true opinion when filling in the questionnaire. Nevertheless, it is assumed that this percentage is small and does not change the overall results, and it is still the best technique to obtain primary data for our research question. In this research, all variables were measured on a five-point Likert type scale; except for few open ended questions. Then, logit models have been estimated using the Eviews software programme. The general characteristics of High Tech SME respondents can be seen from Table 1. 
Table 1: General Characteristics of High Tech SME respondents

\begin{tabular}{|l|lc|}
\hline \multicolumn{1}{|c|}{$\begin{array}{c}\text { Characteristics of SME entrepreneurs } \\
(\mathrm{n}=225)\end{array}$} & Category & Percent \\
\hline Sex & Male & 73 \\
& Female & 27 \\
\hline \multirow{4}{*}{ Education } & PhD & 7 \\
& Post graduate & 23 \\
& University & 37 \\
& High school & 22 \\
& Secondary & 11 \\
\hline Sector & High Tech & 80 \\
& High The Related & 20 \\
\hline Turnover & Up to 5 m TL & 38 \\
& More than 5 m TL & 62 \\
\hline & & \\
Location & istanbul & 100 \\
\hline Characteristics & Mean & SD \\
\hline Number of employees & 11.21 & 5.77 \\
\hline Years in business & 7.44 & 3.56 \\
\hline
\end{tabular}

As seen, most of the respondents are male (73\%), and $37 \%$ of them have higher education; $80 \%$ of the respondents engage in direct manufacturing and $20 \%$ are in high tech related sectors. Almost two thirds of High Tech SMEs have more than 5 million TL turnover and are located in İstanbul. The research question of the present paper is: What are the barriers to innovation faced by Turkish High Tech SME entrepreneurs? To address this research question, we formulate hypotheses to be empirically tested through the use of a logistic regression. The hypotheses presented below aim to identify the significant barriers to innovation on the innovative capability of Turkish High Tech SME entrepreneurs in relation to product innovation and process innovation.

Hypothesis 1: Formal barriers are negatively related to the entrepreneur's propensity for innovation decision in Turkey.

Hypothesis 2: Informal barriers are negatively related to the entrepreneur's propensity for innovation decision in Turkey.

Hypothesis 3: The environmental barriers are negatively related to the entrepreneur's propensity for innovation decision in Turkey.

Hypothesis 4: The lack of skill, technology and information related barriers is negatively related to the entrepreneur's propensity for innovation decision in Turkey.

\subsection{Logit Regression Model}

Because we would like to know what the main barriers to innovation for SME entrepreneurs are, the dependent variable will be dichotomous and the applicable analytical model should come from the binary-choice genre of models (Judge et al. 1985;

Pindyck and Rubinfeld, 1991), namely a Logit model, as the dependent variable, $Y_{i}$ takes the value 1 if the Turkish high tech SME entrepreneurs innovate, that is, when the entrepreneur carried out product or process innovation during 2009-2011. The value 0 is for when the firm does not do this as shown in Equation (1). 


$$
\begin{aligned}
& Y_{i}=\left\{\begin{array}{llll}
1 & \text { if } & \mathrm{Y}_{\mathrm{i}}^{*} & >0 \\
0 & \text { if } & \mathrm{Y}_{\mathrm{i}}^{*} & \langle 0
\end{array}\right. \\
& \mathrm{Y}_{\mathrm{i}}=B X_{i}^{\bullet}
\end{aligned}
$$

$$
\text { where } \mathrm{B}=\left[\begin{array}{llll}
\beta_{1} & \beta_{2} & \ldots & \beta_{k}
\end{array}\right] \text { and } \mathrm{X}_{\mathrm{i}}^{\bullet}=\left[\begin{array}{lll}
1 & X_{i 1} & \ldots X_{i k}
\end{array}\right]
$$

If the innovative status is adopted for the period 2009-2011 when the SME entrepreneur produces or starts the innovation process, the binary logit model Equation (2) can be written as:

$$
\mathrm{Y}_{\mathrm{i}}=\beta_{0}+\beta_{\mathrm{i}} \mathrm{X}_{\mathrm{i} 1}+\beta_{2} \mathrm{X}_{\mathrm{i} 2}+\ldots+\beta_{\mathrm{k}} \mathrm{X}_{\mathrm{ik}}+u_{i}>0 \quad \mathrm{i}=1 \ldots \mathrm{N}
$$

where the innovation decision of the firm $i$ is a function of a set of explanatory variables $X_{i k}$ that explain the barriers to innovation that an entrepreneur perceives; $\beta_{i}$ are the corresponding coefficient vectors, and $u_{i}$ is the usual error term, which we assume to be iid $N(0, \sigma 2)$, and $\sigma 2=1$.

In the literature, the probit and logit models are quite comparable and give qualitatively similar results. According to Griffiths et al. (1993) "because the logistic CDF is not in integral form, that makes the logit model somewhat easier to work with" (p.751). Gujarati also points out that "the logit model is generally used in preference to the probit" Gujarati (2002, p.67). Similarly, Pindyck and Rubinfeld consider "the logit model to be somewhat more appealing then the probit model" (Pindyck and Rubinfeld 1991, p.256). In particular, logit regression is an approach used in studies of high tech firms (Kaufmann and Tödtling, 2001; Silva and Leitão, 2007). Therefore, we also utilise the logit model in this paper.

\subsection{Variables and Estimation of Model}

The choice of variables that were included in the questionnaire was based on a review of the literature (Riding and Swift, 1990; Pack, 1992; Brush, 1992; Evenson and Westphal, 1995; Rodrik, 1995; OECD, 1998; Johnson et al., 2000; Glas et al., 2000; Pissarides et al., 2000; Smallbone and Welter, 2001; Barlett and Bukvic, 2001; Muent etal., 2001; and Aidis, 2002). The probability of innovating is influenced by the following factors:

a) Those such as firm size, R\&D activities and the competitiveness of products are to determine firm specific characteristics.

b) In order to determine formal barriers, lack of government's R\&D policy, instability of tax policies, too much business legislation, insufficient property rights and fulfilling regulations and standards have been selected as variables.

c) Similarly, corruption, the negative impact of the informal economy on investment, cultural attitudes and a lack of transparency are assumed to represent informal barriers.

d) For environmental barriers, excessive perceived economic risks, the high cost of innovation, high inflation and interest rates and a lack of appropriate sources of finance are selected.

e) Finally, for skill barriers, the lack of qualified personnel, a lack of information on markets and the lack of information on technology are identified. The logit estimation results can be seen from Tables 2-7.

Model 1, in Table 2 explains the results of the systematic relations between the entrepreneurial innovative capability and the barriers to innovation in Turkish case. Since some of the variables associated to the barriers are not statistically significant at a level of $5 \%$, (there are only seven statistically significant variables), we estimate Model 2 . In addition to insignificant variables, Model 1 also shows that there is multicollinearity between independent variables, and $R$ square values do show that they are highly correlated. As some of the formal, informal, environmental and skill related hypotheses were not 
empirically tested, the second estimation of the model, Model 2 in Table 2, was set without considering those insignificant variables.

Table 2: Logit Regression Results for SME Entrepreneurs and Innovation Barriers

\begin{tabular}{|l|c|c|}
\hline & Model 1 & Model 2 \\
\hline Independent Variables & Coefficients & Coefficients \\
\hline & 0.79 & 0.63 \\
Constant & $(-0.41)$ & $(-0.30)$ \\
\hline
\end{tabular}

Dependent Variable

Yi=1, innovation happens,

$Y i=0$, innovation does not happen 
Table 3: Firm Specific Characteristics Determinants to Barriers

\begin{tabular}{|l|c|c|}
\hline Firm Size (log) & 0.03 & - \\
& $(0.62)$ & \\
\hline Intensity of R\&D/per employee (log) & $0.33^{* *}$ & $0.31^{* *}$ \\
& $(2.60)$ & $(2.33)$ \\
\hline \multirow{2}{*}{ Education of the entrepreneur (dummy) } & $0.14^{* *}$ & $0.11^{* *}$ \\
& $(2.42)$ & $(2.19)$ \\
\hline \multirow{2}{*}{ Turnover of the company (log) } & -0.31 & - \\
& $(-0.04)$ & \\
\hline
\end{tabular}

Table 4: Formal Barriers to Prevent Innovation

\begin{tabular}{|l|c|c|}
\hline $\begin{array}{l}\text { Lack of Government's R\&D and technology } \\
\text { policy }\end{array}$ & $\begin{array}{c}-1.52^{* *} \\
(-2.38)\end{array}$ & $\begin{array}{c}-1.21^{* *} \\
(-2.32)\end{array}$ \\
\hline Instability of tax policies & $\begin{array}{c}2.56 \\
(-1.48)\end{array}$ & ---------- \\
\hline Too much government regulation & $\begin{array}{c}1.15 \\
(-1.0) 7\end{array}$ & --------- \\
\hline Insufficient property rights & $\begin{array}{c}4.81 \\
(0.06)\end{array}$ & ---------- \\
\hline Inappropriate standards & -1.54 & - \\
& $(-1.31)$ & ------ \\
\hline
\end{tabular}

Table 5: Informal Barriers to Prevent Innovation

\begin{tabular}{|l|c|c|}
\hline Corruption & -0.58 & -------- \\
\hline \multirow{2}{*}{ Informal economy's (-) impact on investment } & $-1.98^{* *}$ & $-1.99^{* *}$ \\
& $(-2.99)$ & $(-2.67)$ \\
\hline \multirow{2}{*}{ Cultural attitudes to bribery } & 3.08 & \\
& $(0.72)$ & -------- \\
\hline \multirow{2}{*}{ Lack of transparency } & -0.88 & \\
\end{tabular}

Table 6: Environmental Barriers to Prevent Innovation

\begin{tabular}{|l|c|c|}
\hline Excessive perceived economic risks & 0.05 & -------- \\
\hline \multirow{2}{*}{ High cost of innovation } & $(0.02)$ & $-1.20^{* *}$ \\
& $-1.72^{* *}$ & $(3.21)$ \\
\hline \multirow{2}{*}{ Lack of appropriate source of finance } & $-1.37^{* *}$ & $-1.11^{* *}$ \\
& $(2.45)$ & $(2.37)$ \\
\hline \multirow{2}{*}{ High inflation and interest rates } & -1.55 & - \\
& $(-1.31)$ & \\
\hline
\end{tabular}

Table 7: Skill Barriers to Prevent Innovation

\begin{tabular}{|l|c|c|}
\hline Lack of qualified personnel & $\begin{array}{c}-0.57^{* *} \\
(3.11)\end{array}$ & $\begin{array}{c}-0.68^{* *} \\
(2.44)\end{array}$ \\
\hline Lack of staff information on technology & $\begin{array}{c}0.33 \\
(1.00)\end{array}$ & --------- \\
\hline Lack of understanding of the market & $\begin{array}{c}-0.03 \\
(-0.04)\end{array}$ & - \\
\hline Diagnostics & 225 & 225 \\
\hline Number of Observations & -57.27 & -57.11 \\
\hline Log Likelihood Function & $25.54^{* *}$ & $25.00^{* *}$ \\
\hline Likelihood Ratio Test & 0.77 & 0.70 \\
\hline Percent Correctly Predicted & 0.21 & 1.20 \\
\hline Madalla $R^{2}$ & 0.17 & 1.16 \\
\hline McFadden $R^{2}$ & & \\
\hline
\end{tabular}

P value is significant at ${ }^{* * *} 0.01, * * 0.05,{ }^{*} 0.10$. 
In terms of firm specific characteristics, "intensity of R\&D/per employee" and "education of the entrepreneur" are the significant variables to innovate for SME entrepreneurs in Turkey. In Model 2, we identify that all the estimators of the regression parameters are statistically significant up to 5\%, and multicollinearity problems from our estimation in Model 2 is eliminated. The predictive capacity of the model is $70 \%$, which results from the comparison between the predicted and the observed values of the answer variable. The log-likelihood statistic, comprising 57.11, also corroborates the global significance of the model, when compared with the null model. The obtained results show that most of the variables associated with barriers to innovation present a negative signal, for which reason they are considered as restraining factors that may influence entrepreneurial innovative activities and consequently lead to a decrease in the firm's propensity for innovating. The results of the model suggest that "lack of government's R\&D and technology policy" as a formal barrier to innovation has a significant effect on the entrepreneur's propensity for innovating. That means, SME entrepreneur's propensity to innovate gets smaller with the clear and non-existent government R\&D and technology policy. That also means that $H 1$ hypothesis is been confirmed. On the other hand that does not mean that government has not got any policy, but it means that this policy has not been perceived by the entrepreneur as an existent policy. The obtained results are similar to other empirical studies (Piatier, 1984; Silva and Leitão 2007; Rush and Bessant, 1992; Hadjimanolis, 1999; Segarra-Blasco et al., 2008; Baldwin and Gellatly, 2004). "Informal economy's negative impact on investment" as one of the informal barriers is another variable, which has a significant effect on the entrepreneur's propensity for innovating decisions. That means that when the informal economy becomes larger, then the entrepreneur's innovative decision probability gets smaller, and consequently the hypothesis $\mathrm{H} 2$ is sustained. These obtained results are also on the same line with some studies (Piatier, 1984; Baldwin and Gellatly, 2004). When we test the null hypothesis, H3, for environmental barriers, we also confirm that "high cost of innovation" and "lack of appropriate source of finance" are two other statistically significant variables, which have a significant impact on the propensity of entrepreneur's innovation decision. Entrepreneurs who consider the innovation costs to be excessive have a smaller propensity for innovating in their decisions (Silva and Leitão, 2007; Tourigny and Le, 2004; Segarra-Blasco et al., 2008; Madrid-Guijarro et al., 2009). Finally, the results of the model show that "lack of qualified personnel" like Segarra-Blasco et al., 2008; Piatier, 1984; Ylinenpää, 1998; Silva et al.; 2007; Rush and Bessant, 1992; Hadjimanolis, 1999; and Rammer et al. (2005, 2006), have a significant effect in the propensity to innovate. The rejection of the null hypothesis of nonexistent relation amongst variables, allows the confirmation of the $\mathrm{H} 4$ hypothesis. Thus, firms that perceive "lack of qualified personnel" show lower propensity to innovate, Therefore, if the entrepreneur perceives the fact that access to qualified personnel is a problem, $s /$ he has no incentive to innovate, and then this consciousness ends up creating a barrier to innovation.

\section{CONCLUSION}

The survey results show that entrepreneurs, who know how to innovate, are those who have more perception of the barriers to innovation. However it is observed through the logistic regression model that some of the relations established between the barriers to innovation and the entrepreneurial innovative capacity are not statistically significant. Our analysis shows that eleven variables out of sixteen are statistically insignificant for high tech SME entrepreneurs in Turkey. Our regression results indicate that only five independent variables are statistically significant among all barriers to innovation groups, therefore, we do not reject our four hypotheses. The results provide insights that "lack of government's R\&D and technology policy"; "informal economy's negative impact on investment"; "high cost of innovation", "lack of appropriate source of finance"; "lack of qualified personnel" have a negative and significant effect on the innovation propensity and the perception of entrepreneurs in Turkey, which are also in line with the findings of Piatier (1984), Keegan et al. (1997), Sener et al. (2014), Segarra-Blasco et al. (2008) and Cooney et al. (1996). Sener et al. (2014) also stated that SMEs form 99,9\% of the industry in Turkey however only 55\% of the SMEs are operating in value added sectors. Therefore, they need government financial support programmes and policy initiatives for increasing their levels of global competitiveness. In particular, governments' R\&D and technology policies that encourage and support innovation among all firms, especially small firms, can help countries remain competitive in a global market. Therefore, government should change the perception of entrepreneurs to support their competitiveness in the global market. Public policy that encourages innovation and improves the education of the labour can enable firms to remain competitive and survive, both of which have direct implications for employment and a country's economic viability. The results may also be insightful for entrepreneurs who are attempting to engage with innovation. Understanding barriers can assist entrepreneurs in fostering an innovative culture by supporting new ideas or by avoiding an attitude that creates resistance to new ideas. 


\section{REFERENCES}

Acs, Z. and Audretch, D. (1988), "Innovation in Large and Small Firms: An Empirical Analysis", American Economic Review Vol.78, No. 4, pp. 678-690.

Acs, Z. and Audretch, D. (1990), Innovation and Small Firms, Cambridge MA.

Aidis, R. (2002), “Why don't we see more SMEs in Luthuania?”, Timbergen Institute Discussion Paper, TI 2002-0389/2.

Anderson, A., Jack, S. and McAuley, A. (2001), "Periphery? What periphery? Marketing to a state of mind", Marketing Review, Vol. 14, No.1, pp. 26-34.

Anderson, T., Serger, S. S., Sorvik, J. and Nasson, E. W. (2004), "The Cluster Policies" Whitebook; IKED Memmo.

Arora, A., Fosfuri, A., and Gambardella, A. (2002), Markets for Technology: The Economics of Innovation and Corporate Strategy, Cambridge, MA

Baldwin, J., and Lin, Z. (2002), "Impediments to advanced technology adoption for Canadian manufacturers", Research Policy, Vol. 31, No.1, pp. 1-18.

Baldwin, J.R. and Gellatly, G. (2004), Innovation Strategies and Performance in Small Firms, Ottawa.

Barlett, W. and Bukvic, V. (2001), “Barriers to SME Growth in Slovenia”, MOCT_MOST, 11, pp. 177-195.

Baron, R. and J. Tang (2009), "The role of entrepreneurs in firm-level innovation: Joint effects of positive affect, creativity, and environmental dynamism" Journal of Business Venturing, 26, pp. 49-60.

Bobera, D. (2013), “Barriers To Innovation In Northern Backa County”, Discussion Paper

Brush, C. (1992), "Research on Women Business Owners: Past Trends, A New Perspective and Future Directions", Entrepreneurship, Theory and Practice, pp. 5-30.

Buggie, F. (2001), "The four phases of innovation”, The Journal of Business Strategy, Vol. 22, No. 5, pp. 36-43.

Cooney, T. M., and O'Connor, A. (1996), "A survey of perceived barriers to innovation across countries", Paper presented to EFMD 25th Small Business Seminar, Cyprus, Sept.

Cooper, R. J. (1998), “A multidimensional approach to the adoption of innovation”, Management Decision, Vol. 36, No. 8, pp. 493-502.

Davidsson, P. (1989), Continued Entrepreneurship and Small Firm Growth. Diss. Stockholm School of Economics, April.

Drucker, P. (1985), Innovation and Entrepreneurship, Macmillan, Basingstoke

Drucker, P. F. (1994), Innovation and entrepreneurship: Practice and principles. London: Heinemann.

Evanson, R. E. and Johnson, D. N. K. (1998), “Invention in Less-Developed Countries”, Mimeo Wellesley College and Yale University.

Evenson, R. E. and Westphal, L. E. (1995), "Technological Change and Technological Strategy", in J. Behrman and T. N. Srinivasan, (eds) Handbook of Development Economics, Amsterdam, North-Holland, 2211-99.

FES (2004), "SME and Innovation”, Friedrich-Ebert-Stiftung Paper 10/2004, Bonn

Fransman, M. (1985), "Conceptualizing Technical Change in the Third World in the 1980s; An Interpretative Survey", Journal of Development Studies, Vol. 21, No. 4, pp. 572-652.

Freel, M., (2005), "Patterns of innovation and skills in small firms", Technovation, Vol. 25, pp. 123-134.

Galia, F., and Legros, D. (2004), “Complementarities between obstacles to innovation: Evidence from France”, Research Policy, Vol. 33, No. 8, pp. 1185-1199.

Gatrell, J. (2001), “Integrated dependence: knowledge-based industries in peripheral regions", Economic Development Review, Vol. 17, No. 3, pp. 63-9.

Glas, M., Drnovsek, M. and Mirtic, D. (2000), "Problems faced by new entrepreneurs; S; ovenia and Croatia", in 30 ${ }^{\text {th }}$ European Small Business Seminar, Gent, Belgium.

Griffiths, W. E., Hill, R. C. and Judge, G. G. (1993), Learning and Practicing Econometrics, New York: John Wiley and Sons, Inc.

Grupp, H. (2001), Managing new product development and innovation: A microeconomic toolbox. Cheltenham: Edward Elgar.

Gujarati, D. N. (2002), Basic Econometrics, $3^{\text {rd }}$ Ed., New York: McGraw-Hill, Inc.

Hadjimanolis, A. (1999), "Barriers to innovation for SMEs in a small less developed country (Cyprus)", Technovation, Vol. 19, No. 9, September, pp. 561-570

Hakim, C. (1989), Identifying Fast Growth Small Firms. Employment Gazette, Jan, pp. 29-41. 
Hargadon, A. and Sutton, R. (2000), "Building and innovation factory”, Harvard Business Review, Vol. 78, No. 4, pp. 157-70.

Hattori, R. and Wycoff, J. (2002), "Innovation DNA: a good idea is not enough. It has to create value”, Training and Development, Vol. 56, No. 2, pp. 25-39.

Herbig, P., Golden, E. J., and Dunphy, A. (1994), "The relationship of structure to entrepreneurial and innovative success", Marketing Intelligence \& Planning, Vol.12, No. 9, pp. 37-48.

IKED (2004), "Strengthening Innovation and Technology Policies for SME Development in Turkey', International Organization for Knowledge Economy and Enterprise Development, December, 2004, Malmo.

Johnson, D. (2001), "What is innovation and entrepreneurship? Lessons for large organizations", Industrial and Commercial Training, Vol. 33, No. 4, pp. 135-140.

Johnson, S. and Loveman, G. (1995), Starting over an Eastern Europe: Entrepreneurship and Economic Renewal, Cambridge: Harvard Business School Press.

Johnson, S., Kaufman, D., MacMillan, J. and Woodruff, C. (2000), 'Why do Firms Hide? Bribes abs Unofficial Activity After Communism", Journal of Public Economics, Vol. 76, pp. 495-520.

Judge, G. G., Griffiths, W. E., Hill, R.C., Lutkeponl, H. and Lee, T. (1985), The Theory and Practice of Econometrics. (Eds.) New York: John Wiley and Sons.

Kanungo, R.N. (1998), Entrepreneurship and innovation: Models for development. London: Sage.

Kaufmann, A. and Tödtling, F. (2001), "Science-industry Interaction in the Process of Innovation: the Importance of Boundary-crossing Between Systems", Research Policy, 30, pp. 791-804.

Keegan, J., O’Connor, A., Cooney, T., Ylinenpää, H., Barth, H., Vesalainen, J., Pihkala, T. Deschoolmeester, D., and Debbaut, A. (1997), Facing The Challenge - Towards a Better Understanding of Barriers to Innovation in Irish, Swedish, Finnish and Belgian SMEs. Paper presented to EFMDs $27^{\text {th }}$ European Small Business Seminar in Rhodes, Greece, September.

Kirzner, I. M. (1985), Discovery and the Capitalist Process, Chicago: The University of Chicago Press, 1985, pp. 10-70.

KOSGEP (2004), Saha Arastirma Calismasi On Degerlendirme, Raporu, Ankara

Kumar, N. and Sagip, M. (1996), “Firm-size, opportunities for Adaption and in-house R\&D Activity in Developing Countries; The Case of Indian Manufacturing", Research Policy, Vol. 25, No. 5, pp. 713-22.

Lall, S. (1983), “Determinants of R\&D in an LDC; The Indian Engineering Industry", Economics Letters, Vol. 13, pp. $379-383$.

Lall, S., Barba-Navaretti, G., Teitel, S. and Wignaraja, G. (1994), Technology and Enterprise Development-Ghana under Structural Adjustment. Macmillan Press, Hampshire, UK.

Legge, J., and Hindle, K. (1997), Entrepreneurship: How innovators create the future. Melbourne: MacMillian Publishers.

Leibenstein, H. (1995), "The Supply of Entrepreneurship," Leading Issues in Economic Development, New York: Oxford University Press, pp. 273-275.

Levy, B. (1993), “Obstacles to Developing Indigenous Small and Medium Enterprises: An Empirical Assessment", The World Bank Economic Review, Vol. 7, No.1, pp. 65-83.

Madrid-Guijarro, A., Domingo, G. and Howard, V. A. (2009), "Barriers to Innovation among Spanish Manufacturing SMEs", Journal of Small Business Management, Vol. 47, No. 4, October, pp. 465-488.

Majaro, S. (1988), Managing Ideas for Profit, McGraw-Hill, London.

March, I., Ganasekaran, A., and Lloria, B. (2002), "Product development process in Spanish SMEs: An empirical research", Technovation, Vol. 22, pp. 301-312.

Marshall, A. (1890: 1920), Principles of Economics. $8^{\text {th }}$ Edition. London: Macmillan and Co., Ltd

Mill. J. S. (1848: 1909), Principles of Political Economy with some of their Applications to Social Philosophy. London; Longmans, Green and Co.

Mohnen, P. and Röller, L. (2005), “Complementarities in innovation policy”, European Economic Review, Vol. 49, pp. 1431-1450.

Mohnen, P. and Rosa, J. (1999), "Barriers to Innovation in Service Industries in Canada,Science and Technology Redesign Project", Research Paper No. 7, Ottawa.

Mohnen, P. and Rosa, J. (2002). "Barriers to innovation in service industries in Canada”, In M. Feldman, and N. Massard (Eds.) Institutions and systems in the geography of innovation (pp. 231-250). Boston: Kluwer.

Mosey, S., Clare, J. and Woodcock, D. (2002), "Innovation decision making in British manufacturing SMEs", Integrated Manufacturing Systems, Vol. 13, No. 3, pp. 176-83. 
Muent, H., Pissarides, F. and Sanfey, P. (2001), "Taxes, Competition and Finance for Albanian Enterprises: Evidence from a Field Study", MOCT-MOST, 11, 2390251.

Organisation for Economic Cooperation and Development (1998), Women Entrepreneurs in Small an Medium Enterprises. Paris: OECD.

Organisation for Economic Cooperation and Development (2003), Managment Training in SMEs: Synthesis Report. Paris: OECD.

Organisation for Economic Cooperation and Development (2004), Small and Medium-Sized Enterprises in Turkey: Issues and Policies, Paris: OECD

Organisation for Economic Cooperation and Development Leed Programme, International Conference (2009), On SMEs, Entrepreneurship and Innovation, Paris: OECD

Pack, H. (1992), "New Perspectives on Industrial Growth in Taiwan", in G Ranis, (eds). Taiwan: From Developing to Mature Economy, Boulder, Colorado: Westview Press, pp. 73-120.

Piatier, A. (1984), Barriers to Innovation. Frances Pinter, London.

Pissarides, F., Singer M. and Svejnar, J. (2000), "Objectives and constraints of entrepreneurs: Evidence from small and medium-sized enterprises in Russia and Bulgaria", European Bank for Reconstruction and Development, Publisher, Place

Porter, M. (1990), The Competitive Advantage of Nations, Macmillan, London.

Pyndyck, R. S. and Rubinfeld, D. L. (1991), Econometric Models and Economic Forecasts, 3rd Ed., New York: Mc-Graw Hill, Inc.

Riding, A. L. and Swift, C. S. (1990), "Women Business Owners and Terms of Credit: Some Empirical Findings of the Canadian Experience", Journal of Business Venturing, Vol. 5, pp. 327-40.

Rodrik, D. (1995), "Trade and Industrial Policy Reform", in J. Brhrman and T. N. Srinivasan, (eds), Handbook of Development Economics, Amsterdam: North-Holland, pp. 2927-82.

Rothwell R. (1991), “Networking and Innovation In European Manufacturing Firms”, Technovation, Vol. 11, No. 1, 93: 112.

Rush, H. and Bessant, J. (1992), "Revolution in three-quarter time: lessons from the diffusion of advanced manufacturing technologies", Technology Analysis and Strategic Management Vol. 4, No. 1: 3-19.

Schumpeter, J. A. (1911), The Theory of Economic Development. Harvard (reproduced, New York 1961).

Schumpeter, J. A. (1942), Capitalism, Socialism, and Democracy. New York: Harper and Brothers. (Harper Colophon edition, 1976.)

Schumpeter, J. A. (1951), "Economic Theory and Entrepreneurial History", in R. V. Clemence (eds), Essays on Economic Topics of Joseph Schumpeter. Port Washington, NY: Kennikat Press

Segarra-Blasco, A., Garcia-Quevedo, J., and Teruel-Carrizosa, M. (2008), "Barriers to innovation and public policy in Catalonia", International Entrepreneur Management Journal, Vol. 4, pp. 431-451.

Sener, S., O. Aydın and M. Savrul (2014), "Structure of Small and Medium-Sized Enterprises in Turkey and Global Competitiveness Strategies", Procedia - Social and Behavioral Sciences 150:212-221

Silva, M. and Leitão, J. (2007), "Determinant Factors of Innovation Capability of Portuguese Services Firms: A Logit Model”, proceedings XVII International RESER Conference "Service Competitiveness and Cohesion - Balancing Dynamics in the Knowledge Society", 13-15 September 2007, Tampere Hall, Tampere, Finland

Smallbone, D. and Welter, F. (2001), "The Distinctiveness of Entrepreneurship in Transition Economies", Small Business Economics, Vol. 16, pp. 249-62.

Stewart, F. (1977), Technology and Underdevelopment, London, Macmillan.

Stoneman, P. (1995), Handbook of the Economics of Innovation and Technological Change. Oxford: Blackwell.

Storey, D. J. (1994), Understanding the Small Business Sector. London: Routledge.

Sundbo, J. (1998), The Theory of Innovation: Entrepreneurs, Technology and Strategy. MA: Edward Elgar.

Teece, D. J. (1996), "Firm organisation, industrial structure, and technological innovation", Journal of Economic Behaviour and Organisation, Vol. 31, pp. 193-224.

TESK (2005), www.tesk.org.tr/yayin/vitrin/167/29/html

Tidd, J., Bessant, J. and Pavitt, K. (2001), Managing Innovation: Integrating Technological, Market and Organisational Change, Wiley, Chichester.

Tourigny, D. and Le, C. (2004), "Impediments to innovation faced by Canadian manufacturing firms", Economics of Innovation and New Technology, Vol. 13, pp. 217-250, 2004

Utterback, J. M. (1994), Mastering the Dynamics of Innovation. Harvard Business School Press. 
Woodword, R. (2001), "SME support in Post-Communist Countries: Moving from Individual to Co-operative Approaches (Reflections on the Polish Case)', MOCT-MOST, 11; 275-294.

Ylinenpää, H. (1998), "Measures to overcome Barriers to Innovation in Sweden”, Paper EFMD European Small Business Seminar in Vienna, 16.09.1998,online: http://www.ies.luth.se/org/Rapporter/AR9826.pdf, last accessed: 21.05.2006

Zhao, F. (2001), "Managing innovation and quality of collaborative R\&D", Conference Proceedings of 5th International \& 8th National Research Conference, Melbourne. 